\title{
Press Manipulation and Its Negative Impact on the Youth
}

\author{
Ioana Livia Manea, „Al. I. Cuza” University of Iasi, Romania \\ Ioana Anda Popa, „Al. I. Cuza” University of Iasi, Romania
}

\begin{abstract}
Nowadays, manipulation may be regarded as an essential instrument of the "mass industrial society", aiming at the conclusion of certain agreements that are convenient to the issuing party, turning to deceit with falsified arguments, as well as to appeals to emotional or non-rational components. The particular forms that it takes in various fields of social life may be found anywhere, from the political form to the economic one. Press strategies have the capacity of manipulating the young consumer's behaviour, generating numerous negative effects on their everyday life.
\end{abstract}

\section{Keywords}

Manipulation, press, misinformation, advertising message

\section{Jel Codes: M 37}

\section{Manipulation - conceptual delimitations}

According to the Dictionary of Sociology, manipulation represents the action of making a social actor (person, group, collectivity, etc.) think and act in a certain manner that is compatible to the initiator's interests, and not to their own interests, by using techniques such as persuasion, which deliberately distortions the truth, generating the impression of a freedom to think and decide.

Unlike the rational conviction influence, manipulation does not aim at the profound understanding of the situation, but at the generation of a convenient understanding, turning to deceit by falsified arguments, as well as to appeals to emotional or non-rational components. In the case of manipulation, the mean intentions of the one who transmits the message cannot be seized by the manipulated person.

Nowadays, manipulation may be regarded as an essential instrument of the "mass industrial society". The particular forms that it takes in various fields of social life may be found anywhere, from the political form to the economic one.

\section{General forms and methods of manipulation}

Persuasion - it represents the action of convincing someone, one way or another, to do something. This is the action by means of which the author of a message supports an idea, trying to convince the auditory. The person who takes a decision does it several times based on other types of arguments than the logical or logically correct ones, being convinced by the apparent "necessity" or "importance" of that particular action or thing.

Persuasion does not include negative intentionality (it does not hide facts, but merely underlines the favorable ones); it is related to the force of argumentation, to the speaker's convincing skills, to the way the speaker is able to place the supported idea in the best of lights. Due to its complex structure and its specific language, which combines the force of 
words and drama tricks (tone, mimics, expressive moves), television provides the most persuasive type of message of all mass communication means.

Misinformation represents any intervention on the basic elements of a communication process, an intervention that deliberately modifies the issued messages aiming to generate in receptors certain attitudes, reactions, or actions envisaged by a particular social agent ${ }^{1}$.

Sometimes, it is considered as an equivalent of black propaganda, since it spreads false information.

The misinformation form, the intoxication consists in the over-saturation of sources with false information, in blocking communication channels deceitful, diversionist messages whether in order to prepare public opinion for a massive hit, or in order to discredit an expected accurate message. Its basic instruments are rumors, gossip and tendentious communications.

By means of television, intoxication may generate genuine conflicts of images, and the winner of these conflicts is the one who has invested the most in their own image and who has best sabotaged the image of the other.

\section{Press manipulation: typology and effects}

The manipulating force of the TV screen becomes stronger as it relies on the image granted credibility (what people see on TV with their own eyes is considered to be genuine).

Types of TV manipulation :

- $\quad$ Manipulation by image

- $\quad$ Manipulation by films

- $\quad$ Manipulation by montage

- $\quad$ Manipulation by commentary

- Manipulation by pagination

- Manipulation by omission

- Manipulation by press rumors

- $\quad$ Manipulation by censorship

- Manipulation by the "showing hiding" procedure

- "showing hiding" procedure charisma

- "showing hiding" procedure journalists

- "showing hiding" procedure non-verbal communication means

When examining the psychology of producing media, one immediately discovers many complexities and dimensions. Examples of sub-specialties are: (1) the psychology of persuasion; (2) the psychology of editing; (3) the psychologies of sound, color, attention, cognition; control, games and learning styles ${ }^{2}$.

It is not possible to examine all of the facets of the psychology of producing media in one brief article. I can, however, provide examples and analysis to help show the nature, scope and technique of production psychology.

Celebrity endorsements, film sponsorship, and marketing in magazines, text messages, posters and the internet are encouraging children to eat badly, despite knowing they should be choosing fruit and vegetables, the study for the Office of the Children's Commissioner found.

Children admitted confusing claims on products and mixed messages from the media, schools and parents made it hard to make sensible choices.

${ }_{1}^{1}$ Cf. Cătălin Zamfir (coord.), Dicționar de Sociologie, Editura Babel, Bucharest, 1998, p. 167.

2 Barbara J. Wilson "Designing media message about health and nutrition: What syrayegies are most effective", Jurnal of Nutrition, Education and Behavior, March-April 2007, pag. 513-519 
One boy asked researchers: "There are vegetable extracts in cola - does that mean its healthy?" 3

Youngsters bought into the appeal of brightly-coloured packaging and cartoons on products, as well as free gifts and promotions, finding healthy foods "boring" even though they might like the taste.

They were also attracted to products linked to sports events such as the World Cup or endorsed by healthy-looking celebrities.

One 15-year-old girl told researchers: "When you see a celebrity promoting something, you think 'well they eat that and look great, so I can too'." ${ }^{4}$

We all perceive and experience events. When we go from place to place, such as driving to the market, we experience certain perception edits. While driving, we notice scenery and cars as they pass. The car's engine and radio provide context, continuity and language. Music may influence mood. When we open the door, we step out into a whole new environment. When we enter a building by passing through doors, or climb a stairway or look up at a light, we change points of view.

As a second example, let us examine the psychology of emotions. Sensory psychology or synesthetics represents the study of the experiences resulting from a uniting of the senses. Adding one sense to another facilitates an experience of higher intensity. This concept is central to stimulation strategy in media.

Synesthetics is the study of uniting of the senses. It is the response occurring when one sense is added to another. Synesthetics is perhaps the line of research most critical to the development of media psychology's emotional dimension. In the new media, our total environment is based on multisensory responses to various audio-visual elements.

Synesthetics coupled with television or computer interaction creates sensory rivalry and may create positive or negative experiences or reactions to information, ideas or presentations. Each stimulus may create positive or negative experiences or reactions. One stimulus may create a positive reaction; others may create conflicts of cues or sensory rivalry. The result, in any case, is emotion from a union of senses stimulated by the multimedia experience.

Examples of such experiences include seeing a boat rocked by waves. This may activate a sense of imbalance in an observer to the extent that it causes seasickness. Viewing a painting of an Arctic scene of frost and snow may evoke the sensation of icy cold, producing goose bumps. Hearing an explosion or gunshot may give the illusion of being struck. Looking at a picture of appetizing food may, in turn, evoke sensations of taste and smell. Each of these examples represents a potential behavior or psycho-visual result engendered by a multimedia interaction.

To achieve the results we are after, we must use the psychology of editing described earlier, plus the psychologies of color, sound, movement, situational cognition and storytelling, each of which comes into play when creating these scenarios. ${ }^{5}$

Semantics represents the incisive use of language. Managing language is fundamental to communication and central to our ability to understand. One simple example may be seen where examining the use of the word "quit." "Quit" is a pejorative term of frustration that means "to give up." "Quit" also is a software programming term that is used for programmers when writing code. Unfortunately, it has found its way to the user. The subliminal response to the word "quit" is negative when it is used in educational or consumer programs. Better choices would be "end" or "stop" or "pause" since they convey appropriate meaning without

\footnotetext{
${ }^{3}$ Kara Chin and James U, Mc. Neal "Chinese children's understanding of commercial communications: A comparison of cognitive development and social learning models", Jurnal of Economic Psychology, February 2006, pag. 36-56

${ }^{4}$ Sarah J. Durkon, Susan J. Paxton, Eleonor H. Wertheim, "How do adolescent girls evaluate body dissatisfaction prevention messages?", Jurnal of Adolescent Health, November 2005, pag. 381-390

5 Foxall, R.Gordon, "Behavior analyses and consumer psychology", Jurnal of Economic Psihology, March 1994, pag.5-91
} 
the implications of failure that the word "quit" conveys. Words, their use and articulation, alliteration, intonation and patterns, are central to media communications. ${ }^{6}$

Semiotics is the study of signs and symbols in human communication. Semiotics plays an important role in media because visual symbol manipulation facilitates the human. machine interface. Symbols facilitate understanding, communication and the creation of relationships. Icons enable navigation and control over media pathways. Clear, creative and careful use of symbols gives rise to iconography as a highly developed semiotic skill.

The graphical interface, through which information is made accessible onscreen, is the principal point of contact between the machine and the person. Graphic interface design, iconography and navigation strategies are central to emerging programming architecture and insightful use of symbols. They represent a fundamental skill requirement for those who use media in communication. Microsoft, Netscape, Yahoo and all the other producers search ardently to find symbols and methods that are intuitive, friendly, representational and easy to use. $^{7}$

These several examples illustrate the range and scope of production related media psychology. The various aspects of media psychology come together in production and are manifested in techniques, based on principles of psychology that give us practical parameters and techniques for producing better programs. ${ }^{8}$

\section{Media manipulation and his effects on young people}

Over the last 30 years, the percentage of U.S. children classified as overweight and obese has more than tripled (Anderson and Butcher, 2006; Centers for Disease Control, 2004). The American Academy of Pediatrics notes similar increases in medical complications due to childhood obesity, including Type 2 diabetes, respiratory illness, hypertension, sleep disorders, and depression (Brown, Sibille, Phelps, and McFarlane, 2002). Anderson and Butcher (2006) identified a set of complementary factors contributing to childhood obesity. Most factors were individual in nature, including genetics, reduced rates of physical activity, and increased consumption of high-calorie, low-nutrition foods and beverages (particularly soft drinks). Further, the review noted that the manufactured food industry has witnessed wholesale change since the 1970s (for example, an increased marketing and consumption of convenience foods such as frozen entrees). ${ }^{9}$

This trend spawned a debate about the role that media play in childhood obesity. Most of the concern about the TV-obesity link is based on correlational data. The average child spends over 5 hours a day with media (Roberts and Foehr, 2004), which has caused concern that sedentary media use constitutes a long-term obesity risk (Viner and Cole, 2005). Researchers (Taros and Gage, 1995) also noted an increase in the number of ads in children's media, particularly television. ${ }^{10}$

Separate reports (Domestic Advertising, 2003, 2006; Harris, Kaufman, Martinez, and Price, 2002) have noted better than $20 \%$ increases in total U.S. food advertising spending from 1995 to 1999 and from 2002 to 2005 . Over those periods, $65-70 \%$ of spending was devoted to television.

\footnotetext{
${ }^{6}$ Margaret Handerson Blair, David H. Furse and David W. Stewart, "Advertising in a new competitive environment: Persuading consumer to buy", Business Horizons, November-December 1987, pag.20-26

${ }^{7}$ W. Fred Raij, "Globalization of marketing communication”, Jurnal of Economic Psichology, April 1997, pag. 255-270

${ }^{8}$ Laren T., "Messages for the Masses: Food and Nutrition issues on Television", Jurnal of the American Dietetic Association, Jules 1997, pag. 733-734

${ }^{9}$ Brown, Jane and Witherspoon, Elizabeth, "The Mass Media and American Adolescents Health", Jurnal of Adolescent Health, December 2002, pag 153-170

10 Jennifer L Harris, John A. Bargh and Kelly D. Brownell, „Priming Effects of Television Food Advertising on Eating Behavior", Health Psycology, July 2009, pag.404-413
} 
Two reviews (Carter, 2006; Hastings et al., 2003) concluded that television ads were a probable, albeit small, influence on children's food preferences. Recent evidence has suggested direct correlations between food advertising and children's purchase requests (Borzekowski and Robinson, 2001; O'Dougherty, Story, and Stang, 2006) and overall nutritional intake (Vereecken, Todd, Roberts, Mulvihill, \& Maes, 2006). One study (Lobstein $\&$ Dibb, 2005) found a strong correlation between the amount of advertising (especially for "empty calorie" foods) and the proportion of over-weight children in 10 countries.

Another study made by Kiser Family Foundation and published in The New York Times presents the average number of hours spent by a teenager, using a means of reception. It is presented the average time in 2009 compared with 2004. The results of this study are:

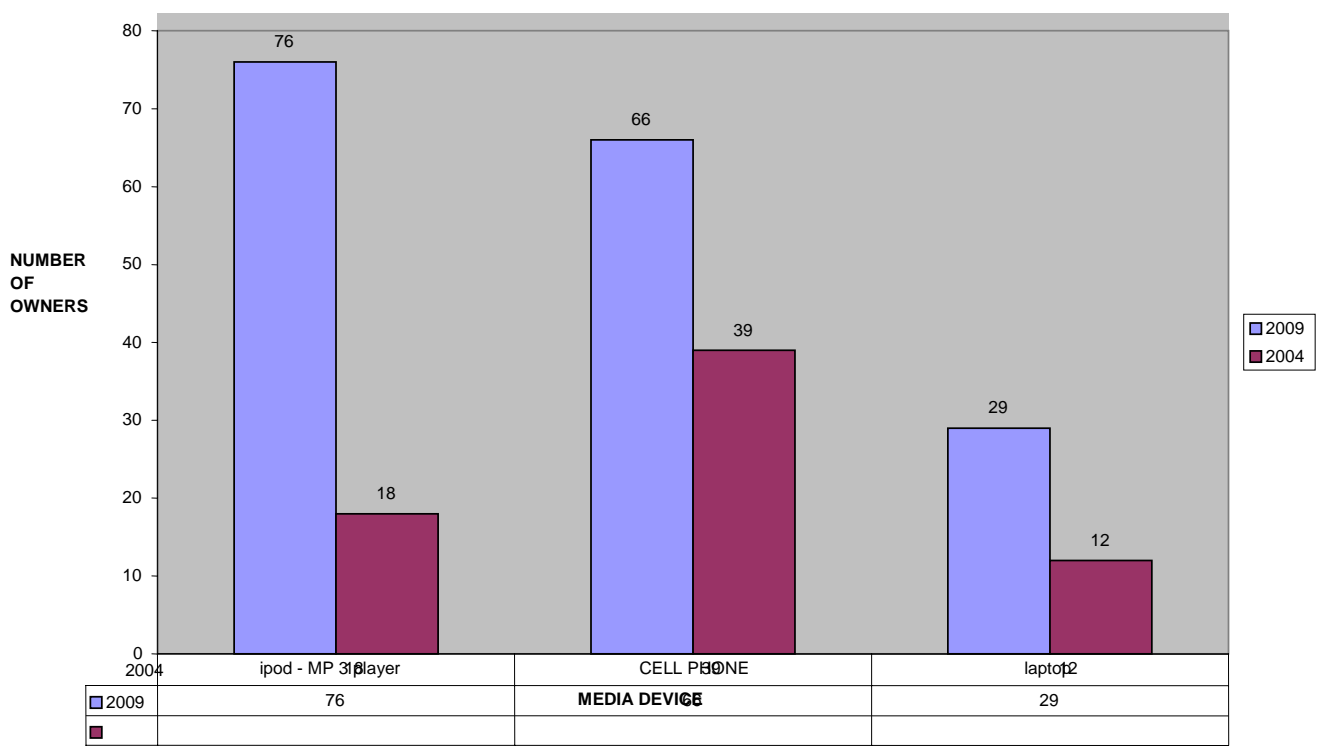

Graphic. 1. Percent of all 8 to 18 years old who own each device

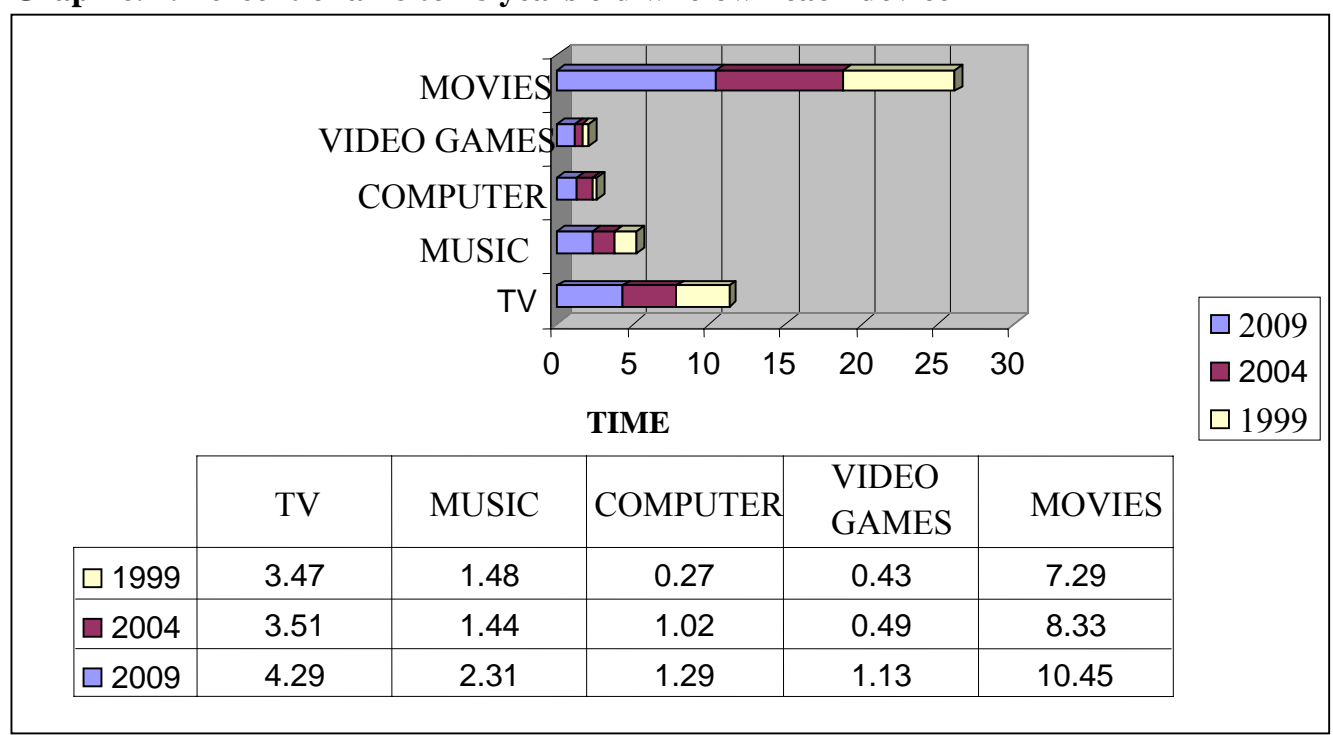

${ }^{11}$ Zwier, Sandra, "Medicalisation of food advertising. Nutrition and health claims in magazine food advertisements 1990-2008", Appetite, August 2009, pag. 109-113 
Graphic. 2. Average hours and minutes spent with each medium in a typical day among 8 to 18 years old

The importance of these content analyses emerges when one considers children's interpretive strategies with television content. Developmental psychology theories are helpful in identifying the audio/visual cues that heighten children's attention and comprehension of advertising. However, effects research indicates that some of these cues can mislead child viewers.

\section{Instead of conclusions - examples of press manipulation in modern and contemporary ages}

An ample international survey made by Gallup in 1986 reveals the following facts: Only 1 out of 4 subjects believe that the great news institution (such as BBC or NBC) are credible;

$79 \%$ of the interviewed individuals believe that press is "literally professional" and that their purpose is to do their job as well as they can.

A similar survey, made 3 years later (1989), shows certain modifications in the audience's perception of how television provides information:

Only $54 \%$ of the interviewed people say that reporters present information in an objective manner;

$44 \%$ think that press is frequently non-objective;

More than two thirds of them (68\%) declare that journalists always tend to favour one of the parties involved in a conflict;

Only $33 \%$ believe that press is independent, most of them thinking that it is influenced by powerful people or politicial groups;

$77 \%$ blame press for invading their privacy.

\section{Bibliography}

1. Anderson, P. M., \& Butcher, K. F. (2006). Childhood obesity: Trends and potential causes. The Future of Children, 16, 19-45.

2. Barbara J. Wilson "Designing media message about health and nutrition: What syrayegies are most effective", Jurnal of Nutrition, Education and Behavior, March-April 2007, pag. 513-519

3. Brown, Jane and Witherspoon, Elizabeth, "The Mass Media and American Adolescents Health", Jurnal of Adolescent Health, December 2002, pag 153-170

4. Brown, W., Sibille, K., Phelps, L., \& McFarlane, K. (2002). Obesity in children and adolescents. Clinics in Family Practice, 4, 3.

5. Domestic advertising spending by category (2003, June 23). Advertising Age, 74(25), S-14.

6. Domestic advertising spending by category (2006, June 26). Advertising Age, 77(26), S-8.

7. Foxall, R.Gordon, "Behavior analyses and consumer psychology", Jurnal of Economic Psihology, March 1994, pag.5-91

8. Fred, W von Raaij "Postmodern consummation", Jurnal of Economic Psychology, September 1993, pag. 541-563

9. Harris, J. M., Kaufman, P., Martinez, S., \& Price C. (2002). The U.S. food marketing system, 2002: Competition, coordination, and technological innovations into the 21st century. USDA Agricultural Economic Report no. 811. Washington, DC: USDA.

10. Hawker, G. (2002) "Food the ultimate delivery system?" Script Magazine, April, 14-17

11. Jennifer L Harris, John A. Bargh and Kelly D. Brownell, „Priming Effects of Television Food Advertising on Eating Behavior", Health Psycology, July 2009, pag.404-413

12. Kara Chin_and James U, Mc. Neal "Chinese children's understanding of commercial communications: A comparison of cognitive development and social learning models", Jurnal of Economic Psychology, February 2006, pag. 36-56 


\section{Studies and Scientific Researches - Economic Edition, no. 15, 2010}

13. Laren T., "Messages for the Masses: Food and Nutrition issues on Television", Jurnal of the American Dietetic Association, Jules 1997, pag. 733-734

14. Margaret Handerson Blair, David H. Furse and David W. Stewart, "Advertising in a new competitive environment: Persuading consumer to buy”, Business Horizons, November-December 1987, pag.20-26

15. W. Fred Raij, “Globalization of marketing communication”, Jurnal of Economic Psichology, April 1997, pag. 255-270

16. Michael, E. Oakes "Good food gone bad: "infamous" nutrients diminish perceived vitamins and mineral content of foods", Appetite, June 2004, pag. 273-278

17. Morasso Gabriella, Bolognesi Claudia, Duglio Elena, Marco Musso, „Pesticides as Food Contaminants: a pilot project for correct public information", Trends in Food Science \& Technology, 10 September 2000, pag. 379-382

18. Ralf Greiner_and Ursula Konietzny „Presence of Genetically Modified Maize and Soy in Food Products Sold Commercially in Brazil from 2000 to 2005", Food Control, May 2008, pag. 499-585

19. Renwich, A., Barlow, S "Risk Characterization of Chemicals in Food and Diet, Food and Chemical Toxicology, September 2003, pag 1211-1271

20. Roberts, D. F., \& Foehr, U. G. (2004). Kids and the media in America. Cambridge, UK: Cambridge University Press.

21. Roe, Brian and Teisl, Maria "Genetically modified food labeling: The impacts of message and messenger on consumers perception of labels and products, Food Policy, February 2007, pag. 49-66

22. Sarah J. Durkon, Susan J. Paxton, Eleonor H. Wertheim, "How do adolescent girls evaluate body dissatisfaction prevention messages?", Jurnal of Adolescent Health, November 2005, pag. 381-390

23. Taras, H. L., \& Gage, M. (1995). Advertised foods on children's television. Archives of Pediatrics and Adolescent Medicine, 149, 649-652.

24. Vereecken, C. A., Todd, J., Roberts, C., Mulvihill, C., \& Maes, L. (2006). Television viewing behaviour and associations with food habits in different countries. Public Health and Nutrition, 9, 244250 .

25. Viner, R. M., \& Cole, T. J. (2005). Television viewing in early childhood predicts adult body mass index. Journal of Pediatrics, 147, 429-435.

26. Zwier, Sandra, "Medicalisation of food advertising. Nutrition and health claims in magazine food advertisements 1990-2008”, Appetite, August 2009, pag. 109-110 